\title{
Fibrous Monolithic Ceramics: I, Fabrication, Microstructure, and Indentation Behavior
}

\author{
Suresh Baskaran, ${ }^{*}$ Stephen D. Nunn, ${ }^{*}$ Dragan Popovic, ${ }^{*}$ and John W. Halloran* \\ Department of Materials Science and Engineering, University of Michigan,
} Ann Arbor, Michigan 48109

\begin{abstract}
Monolithic ceramics have been fabricated from coated green fibers to create fibrous microstructures. The fibrous monoliths consist of high aspect ratio polycrystalline regions (cells) of a primary phase separated by thin secondphase regions (cell boundaries) designed to improve fracture resistance. The cells are the remnants of the green fiber which consists of ceramic powder and a polymer binder. The coating applied on the green fiber forms the cell boundaries. Fabrication and microstructure are described for fibrous monoliths in the $\mathrm{SiC} / g r a p h i t e$, silicon nitride/BN, alumina/alumina-zirconia, alumina/aluminum titanate, alumina/nickel and Ce-TZP/alumina-Ce-zirconia systems. The SiC/graphite fibrous monolith displays noncatastrophic failure in flexure, with shear delamination along the weak graphite layers. Indentations in $\mathrm{SiC} / g r a p h i t e$ cause cells to spall, with crack arrest and extrusion of graphite from the cell boundaries. Crack deflection and spalling of cells are also observed in alumina/alumina-zirconia fibrous monoliths. In the Ce-TZP/alumina system, transformed regions around indentations are significantly modified by the alumina-containing cell boundaries.
\end{abstract}

\section{Introduction}

$\mathbf{M}$ ONOLITHIC ceramics which have a fabric of microstructural features designed to interact with crack propagation have improved toughness and show $R$-curve behavior.' Clegg et $a l^{2}$ produced a laminar fabric of $\mathrm{SiC}$ interleaved with graphite films which had flexural stress-strain behavior comparable to fiber-reinforced composites. Duplex structures of Claussen ${ }^{3}$ and duplex bimodal ceramics ${ }^{4,5}$ are designed with a fabric where the local phase content is varied in a matrix. These result in increasing toughness with crack propagation, or $R$-curve behavior, and lead to flaw-insensitive ceramics.

The "fibrous monolith" processing approach, introduced by Coblenz, ${ }^{6}$ provides a novel and powerful method to fabricate ceramics with controlled fabrics. Fibrous monoliths are sintered (or hot-pressed) monolithic ceramics with a distinct fibrous texture, consisting of cells of a primary phase, separated by cell boundaries of a tailored secondary phase. This structure is illustrated schematically in Fig. 1. The cells are not fibers, but rather polycrystalline ceramic domains. The cell boundary phases can be, in different designs, weak interfaces, microcrack zones,

B. Lawn- contributing editor

\footnotetext{
Manuscript No. 195027. Received December 16, 1992; approved May 17, 1993. This article was originally submitted on July 29,1992 as Manuscript No. 195460. This article was originally submitted on July 29,1992 as Manuscript No. 195460.
Supported by the Defense Advanced Research Projects Agency and the Office of Naval Research under Contract No. N0014-9 [-J-1999.

*Member, American Ceramic Society.
}

ductile-phase filaments, or interphases with different physical properties.

We have produced fibrous monoliths from a variety of materials using a simple process for converting ordinary ceramic powder into "green fiber" consisting of the powder and a soft polymer binder. These fibers can be compacted in the green state to create, after sintering, the fabric of polycrystalline cells. The secondary phases for the cell boundaries are introduced as a coating on the green fiber prior to compaction. The process is widely applicable. The cells and cell boundaries can be made from any compatible set of materials available as fine, sinterable powders. The scale of the microstructure is determined by the green fiber diameter (for cell size) and coating thickness (for cell boundaries). A variety of architectures are possible, including compacted felt structures, randomly oriented chopped green fibers, and aligned green fibers. We have prepared fibrous monoliths in the SiC/graphite, $\mathrm{Si}_{3} \mathrm{~N}_{4} / \mathrm{BN}$, alumina/alumina-zirconia, alumina/aluminum titanate, Ce-TZP/ $\mathrm{Ce}-\mathrm{TZP}-$ alumina, and alumina/Ni systems.

In the simplest system, the cell boundary is a weak interface and acts as the preferred path for crack propagation. Examples are graphite cell boundaries with silicon carbide or boron nitride cell boundaries in silicon nitride. Fibrous monoliths such as alumina/aluminum titanate or alumina/alumina-zirconia are designed to have microcracked cell boundaries that will affect crack propagation characteristics. Microcracking occurs in fine-grained $\mathrm{Al}_{2} \mathrm{TiO}_{5}$ because of high thermal expansion anisotropy. ${ }^{7,8}$ In particulate composites of $\mathrm{Al}_{2} \mathrm{O}_{3}-\mathrm{Al}_{2} \mathrm{TiO}_{5}$, high residual stresses due to expansion mismatch result in flaw-tolerant mechanical behavior.' In alumina matrices containing unstabilized zirconia, microcracking arises from the transformation of zirconia particles from tetragonal to monoclinic symmetry. ${ }^{3}$ An alumina/nickel fibrous monolith has been fabricated as an example of a ductile phase cell boundary. To examine $\mathrm{Ce}-\mathrm{TZP} /$ alumina laminate ${ }^{10}$ in fibrous monolith form, we produced a microstructure with transformable Ce-TZP cells with

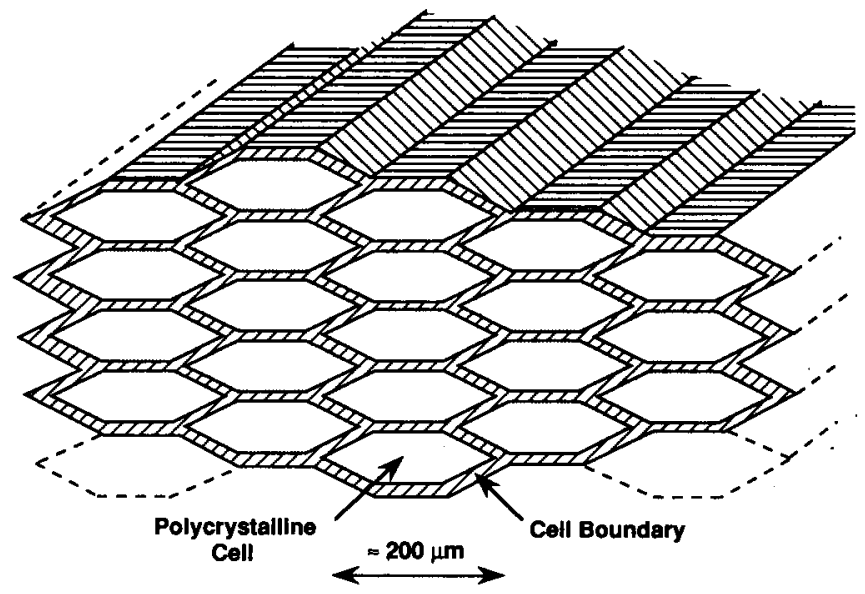

Fig. 1. Schematic illustrating the structure of a fibrous monolith. 
nontransformable alumina $+\mathrm{Ce}$-zirconia cell boundaries. The work of Marshall et al. ${ }^{10}$ has shown that transformation zone spreading in suitably tailored Ce-TZP/alumina structures can significantly increase the fracture toughness.

This paper is a first report on fibrous monolithic ceramics, emphasizing fabrication, microstructure, and indentation behavior of several different systems, and briefly describing the strength behavior of one system, $\mathrm{SiC} / g r a p h i t e$. It will be followed by detailed reports on the mechanical properties of particular types of fibrous monoliths."

\section{Fabrication Procedure}

The fabrication of fibrous monoliths is illustrated in Fig. 2, a process schematic. There are six process steps: (1) spinning the green fiber for the cell, (2) coating the green fiber with the cell boundary material, (3) lay-up of the coated green fibers, (4) consolidation of the soft fibers into a monolithic green body, (5) binder burnout, (6) densification by sintering or hot-pressing.

\section{(I) Fiber Spinning and Coating}

Green fibers are made from any fine ceramic powder and appropriate polymer binders. The polymer system depends upon the fabrication method, with thermoplastics used for melt spinning, and solvent-borne resins used for dry spinning. Ease of processing and good binder behavior are the major considerations in polymer selection. The polymer should produce a flexible green fiber which can be easily deformed during consolidation. Green fibers can be made by any of the conventional fiber-forming methods, including suspension dry spinning, ${ }^{12,13}$ thermoplastic melt spinning, ${ }^{14,15}$ or wet spinning of rayon viscose suspensions. ${ }^{16}$ We prepare fibers by dry spinning and melt spinning.

Dry spinning is convenient for small batches. The dry spinning "dope" is prepared rather like a tape casting slip. In the first ball milling step, the ceramic powder is dispersed in a volatile solvent. The polymer solution is added, followed by a second ball milling step to homogenize the slip, producing a dilute slip. Next the slip is concentrated by evaporating the solvent to produce the viscous spinning dope. The dope is extruded into a drying column to produce the fibers.

The dry-spun fibers used in this work had a dry composition of 55-60 vol\% ceramic powder $+40-45$ vol\% ethyl methacrylate (EMA) copolymer (Acryloid B-7 MEK, Rohm and Haas, Philadelphia, PA). The solvent was methyl ethyl ketone (MEK). The ceramic powders in the green fiber that ultimately form the cell phases are listed in Table I. For extrusion, the dope was loaded into a dispensing syringe with a pneumatic piston, and forced through a $330-\mu \mathrm{m}$ orifice into a drying column at $85-$ $110^{\circ} \mathrm{C}$. For our particular extrusion and drying conditions, spinnable dopes had solvent concentrations in the range of 60
70 vol\% MEK solvent. The preferred compositions, temperatures, and processing variables are reported elsewhere. ${ }^{12}$

Figure 3(A) shows a typical dry-spun green fiber with an area-equivalent circular diameter of $\approx 175 \mu \mathrm{m}$. Notice the "dog-bone" cross section, an artifact of the high evaporation to diffusion rate ratio during dry spinning in this particular system. A high-magnification view (Fig. 3(B)) shows the edge of a coated fiber. The fiber contains a $\mathrm{SiC}\left(+\mathrm{Y}_{2} \mathrm{O}_{3}, \mathrm{Al}_{2} \mathrm{O}_{3}\right)$ ceramic powder and the EMA polymer. We find that unplasticized EMA contents should be at least 20 vol\% for lamination of the green fibers into monolithic bodies. Polymer contents of 40-50 vol\% are preferred for convenient handling of green fibers.

Melt-spun fibers were prepared using methods similar to those described by Frechette et al. ${ }^{15}$ Here the ceramic powder is compounded with a thermoplastic, as in the preparation of injection molding mixes. We use a Brabender Plasticorder (C. W. Brabender Instruments, Inc., South Hackensack, NJ) heated to the appropriate temperature, such as $170-180^{\circ} \mathrm{C}$ for polypropylene (PP) or $180-190^{\circ} \mathrm{C}$ for ethylene vinyl acetate (EVA) (Elvax 470 Du Pont, Wilmington, DE). The resin is melted, and the ceramic powder gradually added while compounding to produce a homogeneous blend. The spinnable mix is a leathery compound consisting of 50 vol\% ceramic powder. Our extruder is a piston-style machine requiring a cylindrical feedrod, so the compounded mix is next formed into a $1-\mathrm{cm}$-diameter feedrod by compression molding. The feedrod is loaded into the fiber extrusion machine (Bradford University Research, Ltd., Bradford, U.K.) and extruded through a spinnerette. Extrusion conditions depend upon the particular system. For silicon nitride-EVA green fiber with a $250-\mu \mathrm{m}$ single-hole orifice, for example, we extrude at $215^{\circ} \mathrm{C}$ and $1-3 \mathrm{MPa}$. The fiber cools rapidly and is taken up on a cross-wound spool about $1 \mathrm{~m}$ below the extruder. Unlike the dry-spun fiber, melt-spun fiber is uniform and round. In this study, only $\mathrm{Si}_{3} \mathrm{~N}_{4}$ green fibers were melt-spun. All other materials were dry-spun.

The cell boundary material is applied by a simple dip coating process in which the green fibers are drawn through a suspension of the coating material. The thickness of the coating is determined by the concentration of the suspension. Figure 3(B) shows $\mathrm{a} \approx 1-\mu \mathrm{m}$-thick graphite coating on $\mathrm{SiC}$ green fiber. The graphite slurry is simply a commercial aqueous graphite paste (Aquadag, Acheson Colloid, Port Huron, MI), diluted with 2-propanol to a low-viscosity suspension of $\approx 3$ vol\% solids. We find that this adheres well to dry-spun fibers with EMA binders. This simple coating is too brittle for melt-spun fibers, which are respooled after coating, so a latex binder (LPR 6632A carboxylated styrene butadiene rubber latex, Goodyear Tire and Rubber Co., Calhoun, GA) is added to the coating slurry to make it adherent and flexible. Boron nitride coatings are applied with a commercial aqueous BN coating slurry (BN Paint, ZYP Coatings, Oak Ridge, TN). The slurry is supplied with 25 wt $\%$

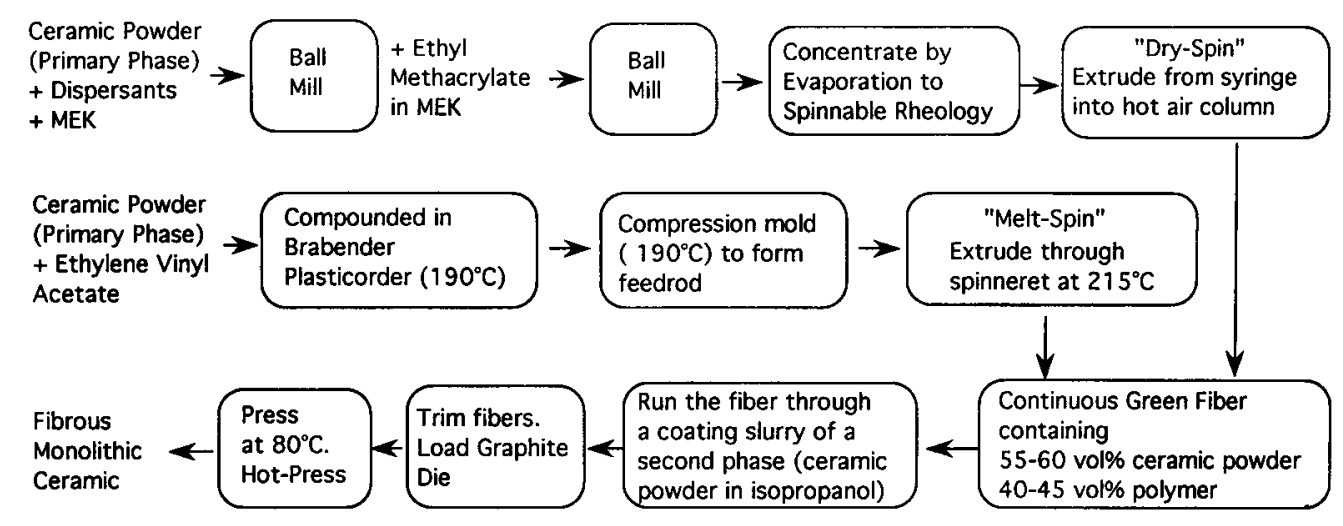

Fig. 2. Flow chart describing fabrication procedure of fibrous monoliths. 
Table I. Fibrous Monolith Systems and Fabrication Conditions

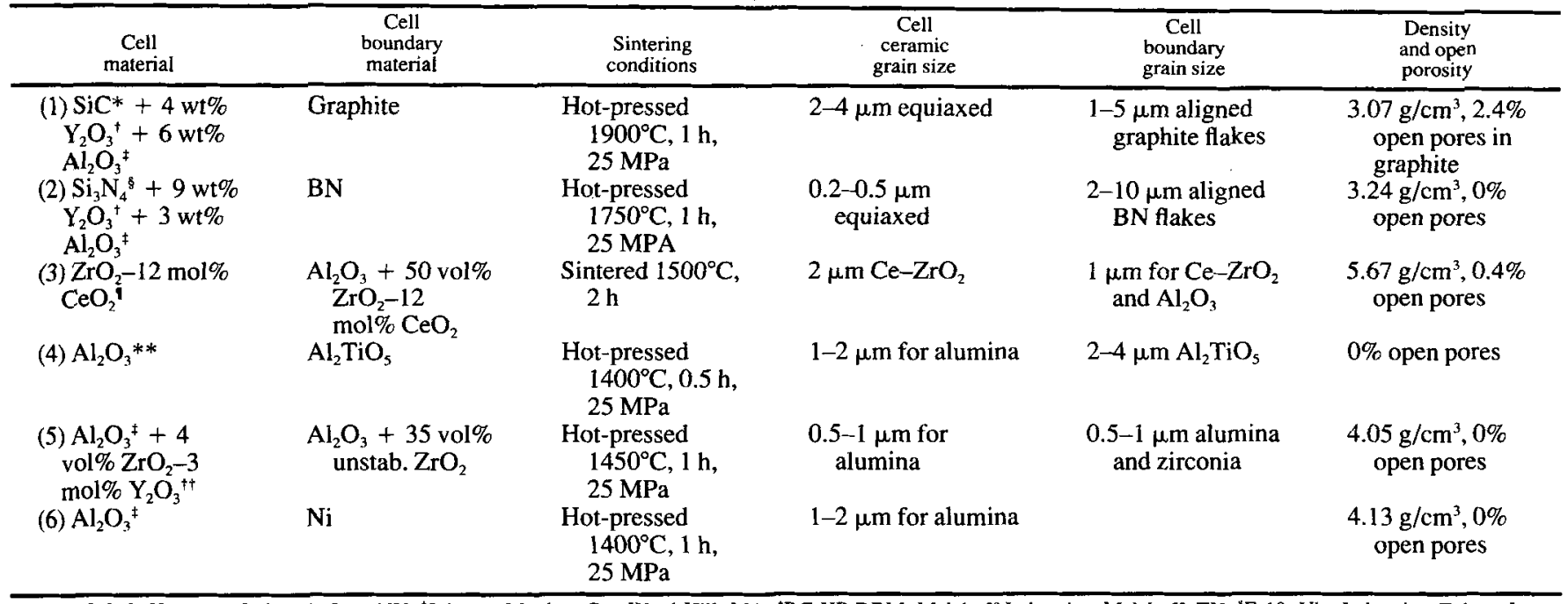

*B-10 B-SiC, Hermann C. Starck, Inc., NY. 'Johnson Matthey Co., Ward Hill, MA. 'RC-HP DBM, Malakoff Industries, Malakoff, TX. "E-10, Ube Industries, Tokyo, Japan. 'TZ-12Ce, $12 \mathrm{~mol}_{\%} \mathrm{CeO}_{2}-\mathrm{ZrO}_{2}$, Tosoh USA, Atlanta, GA. **AKP-50, Sumitomo Chemicals, Tokyo, Japan. ${ }^{\dagger}$ TZ-3Y, Tosoh USA, Atlanta, GA.

solids, with the solids consisting of $87.5 \mathrm{wt} \% \mathrm{BN}$ and $12.5 \mathrm{wt} \%$ alumina.

To produce cell boundaries of aluminum titanate on alumina green fibers, we use a slurry containing the appropriate ratio of reactive submicrometer alumina (RC-HP DBM Malakoff Industries, Malakoff, TX) and titania (J. T. Baker Chemical Co., Phillipsburg, NJ) powders in 2-propanol. The aluminum titanate phase forms via solid-state reaction during sintering. Alumina-zirconia cell boundaries are created by coating alumina green fibers with a similar slurry containing alumina (Malakoff Industries) and unstabilized zirconia powder (SC-101, Magnesium Elektron, Inc., Flemington, NJ). The median particle size of the unstabilized zirconia powder was 0.9 $\mu \mathrm{m}$. Metallic Ni cell boundaries are obtained by coating alumina green fibers with an aqueous suspension of $\mathrm{NiO}(\mathrm{N}-69$, Fisher Scientific Co., Fairlawn, NJ). Reduction to metallic nickel occurs during hot pressing. To produce cell boundaries of Ce-zirconia + alumina on Ce-TZP fibers, we use a slurry containing Ce-zirconia (TZ-12Ce, Tosoh USA, Atlanta, GA) and alumina (Malakoff Industries) powders. All oxide coating slurries contained $\approx 10$ vol\% solids.

\section{(2) Forming}

The fibrous monoliths are formed by warm-pressing a green fiber preform. We make random compacted felt preforms by simply compressing a tangled mass of fiber. Uniaxial layups are made by arranging the green fibers in a uniaxial pattern prior to compaction. Coated green fibers can also be chopped to $<4$-mm lengths, simply poured into the die and pressed. Compaction is conducted at temperatures above the glass transition temperature of the ethyl methacrylate copolymer $\left(40^{\circ} \mathrm{C}\right)$ where the fibers are soft enough to mold under pressure and laminate into a solid monolith. Typically we load the coated green fiber preform into a cold die, warm the assembled die to $80^{\circ} \mathrm{C}$, then compress the preform at $60 \mathrm{MPa}$ in a Carver press. This temperature-pressure condition is sufficient to entirely collapse all the voids between the green fibers.

Uniaxial compaction adds an additional texture to the fibrous monolith, since the soft fibers are mostly deformed along the
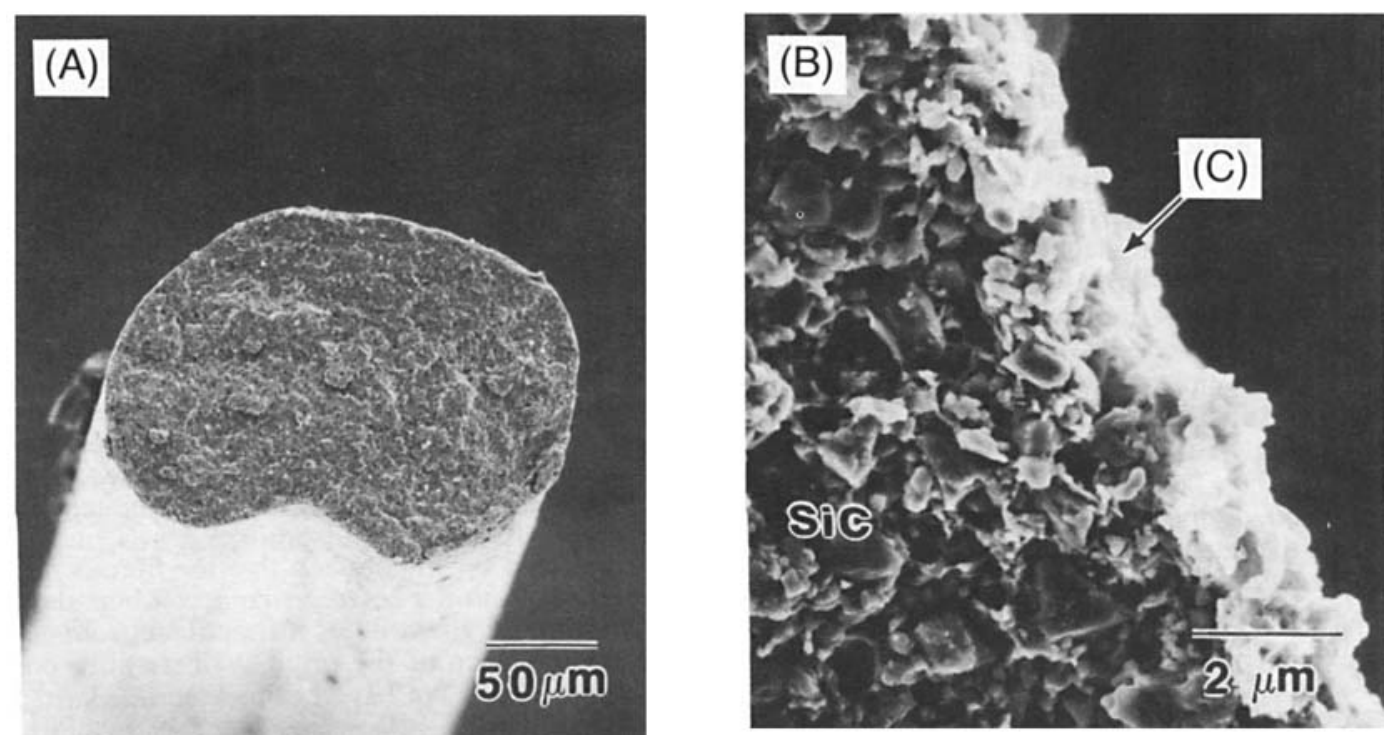

Fig. 3. SEM micrographs of the cross section of a coated $\mathrm{SiC}$ green fiber produced by dry spinning: (A) low-magnification view showing fiber cross section; (B) higher-magnification view near the edge. The fiber consists of $\mathrm{SiC}\left(+\mathrm{Y}_{2} \mathrm{O}_{3}, \mathrm{Al}_{2} \mathrm{O}_{3}\right)$ powder and ethyl methacrylate. The colloidal graphite (C) coating is indicated by arrow. 

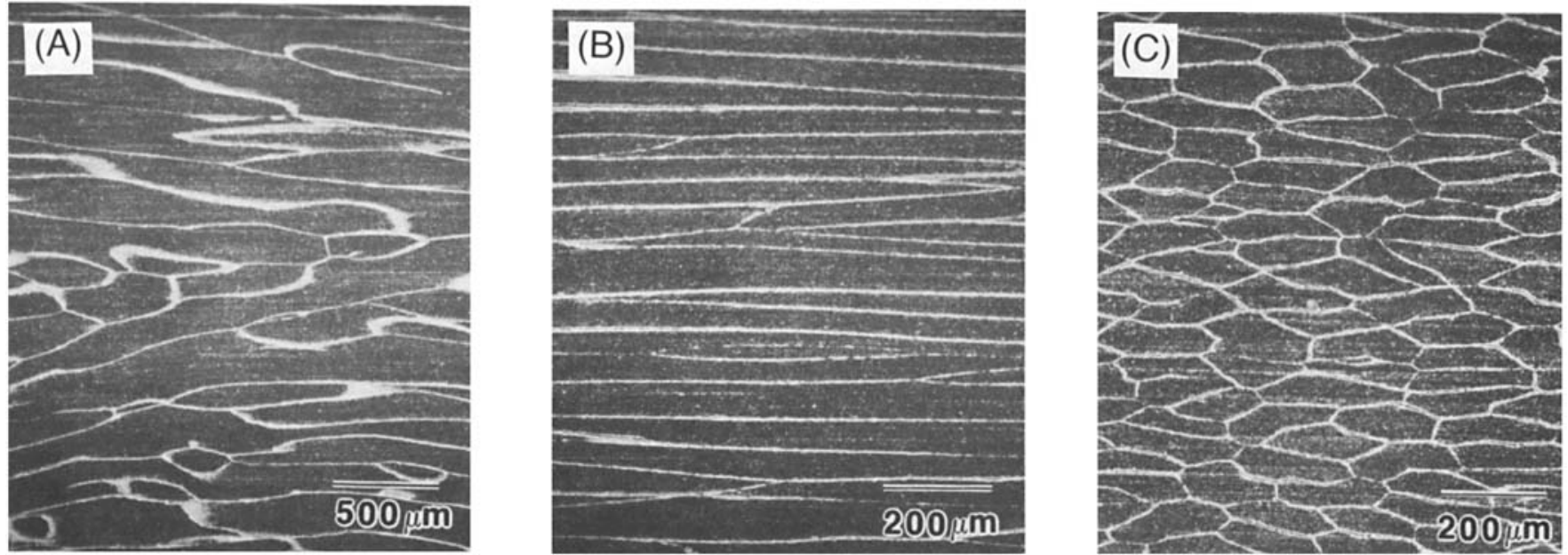

Fig. 4. Ground surfaces of a dense $\mathrm{SiC}$ /graphite fibrous monolith prepared with aligned fibers showing polycrystalline $\mathrm{SiC}$ cells (gray) and graphite cell boundaries (white): (A) viewed in the hot-pressing direction, (B) viewed normal to the hot-pressing direction, (C) end-on view. Fibers were aligned left-right in $(\mathrm{A})$ and $(\mathrm{B})$.

compression axis. Thus typical green fibers with $\approx 175-\mu \mathrm{m}$ equivalent diameters are flattened during warm pressing, and further deformed during uniaxial hot pressing, resulting in cells only $\approx 60 \mu \mathrm{m}$ thick and $\approx 200 \mu \mathrm{m}$ wide after densification. This imparts distinct transverse versus longitudinal microstructure.

The green fibrous monolith undergoes a conventional binder burnout followed by sintering or hot pressing. For oxides sintered in air, binder burnout is done in air. The heating schedule depends upon the size of the green part. For $7-\mathrm{cm}^{3}$ green billets $\left(5.2 \mathrm{~cm}\right.$ wide, $2.6 \mathrm{~cm}$ long, and $0.5 \mathrm{~cm}$ thick), we heat at $60^{\circ} \mathrm{C} / \mathrm{h}$ to $600^{\circ} \mathrm{C}$. After binder removal, oxide pellets or billets are isostatically pressed in rubber bags to $310 \mathrm{MPa}$, and then sintered. The Ce-TZP-based fibrous monolith was fabricated using this procedure. For nonoxide materials which are hot-pressed, such as silicon carbide-graphite, binder removal is accomplished by heating in the graphite die in an actively pumped vacuum. We remove the binder from $7-\mathrm{cm}^{3}$ billets by heating at $260^{\circ} \mathrm{C} / \mathrm{h}$ to $800^{\circ} \mathrm{C}$, while the part is in the graphite die, before hot pressing. For the alumina/aluminum titanate fibrous monoliths, binder removal and sintering can be done in air, but we chose to hotpress in alumina packing powder for convenience.

\section{(3) Densification and Microstructural Development}

Densification is accomplished by sintering or hot pressing at the temperatures appropriate for the particular powder. Table I lists the densification conditions for several systems, along with several microstructural characteristics, such as the grain size of the cell ceramic and the cell boundary material, as estimated from micrographs. Systems 1 and 2, the silicon carbide and silicon nitride materials, are hot-pressed with an yttria-alumina liquid-phase sintering aid. The oxide materials are nominally solid-state densified. The ceria-zirconia fibrous monolith, system 3, was pressureless sintered. All three alumina-based fibrous monoliths were hot-pressed. The aluminas were undoped. Systems 4 and 6 did not have a grain growth inhibitor, while system 5 included 4 vol\% of 3 Y-TZP as a second-phase grain growth inhibitor.

The volume fraction of the cell boundary phases are not exactly known, since the green coating thicknesses are not precisely controlled. Hence we do not know the theoretical densities of the fibrous monoliths. The densities and open porosity, as determined by the water immersion method, are included in Table I. The cell phases in all materials are essentially fully dense. None of the systems imbibe water, so they have no apparent open porosities. The alumina- $\mathrm{Ce}$-zirconia cell boundary phase in the pressureless sintered system 3 appears to have some porosity (or pullout) in polished sections, but the porosity must be too small to cause measurable water adsorption. In the

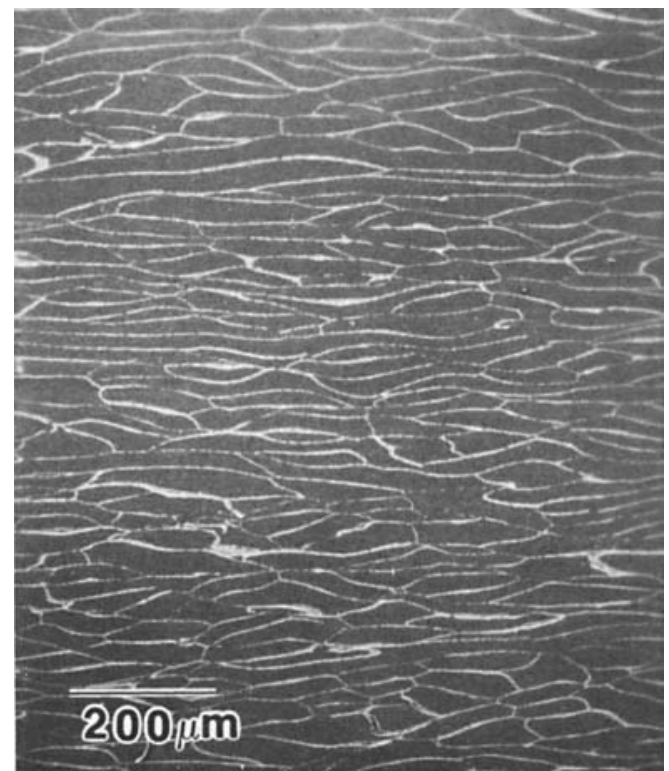

Fig. 5. SEM micrograph of a polished surface of a SiC/graphite fibrous monolith prepared with finely chopped randomly oriented fibers. Viewed normal to the hot-pressing direction.

case of the $\mathrm{SiC} /$ graphite, system 1, the cells are fully dense, but we infer a porosity of $30 \%$ within the graphite cell boundaries. Since the graphite is present at only $4 \mathrm{wt} \%$ overall, this corresponds to about $2.4 \mathrm{vol} \%$ porosity. This material does not adsorb water, so the porosity in the graphite phase is inferred indirectly. ${ }^{11}$ Fabricated graphites are always porous, so we expect some porosity in the graphite cell boundaries. We assume that the silicon nitride/boron nitride analogue, system 2 , has a similar amount of porosity in the BN cell boundaries, although this material also does not adsorb water.

It should be emphasized that the fibrous monolith structure develops from the heterogeneous cell boundary material. Simple uncoated green fiber, if it is made from equiaxed powder, leaves no trace of the original fibers after consolidation and densification.* We have hot-pressed uncoated $\mathrm{SiC}$ green fiber

*However, anisometric particles, flakes, or platelets are aligned during fiber spinning and leave a distinct texture. We are exploring systems such as compacted green fibers of alumina powder + alumina platelets and $\mathrm{SiC}$ powder + graphite flakes to produce monolithic ceramics containing locally oriented features. 


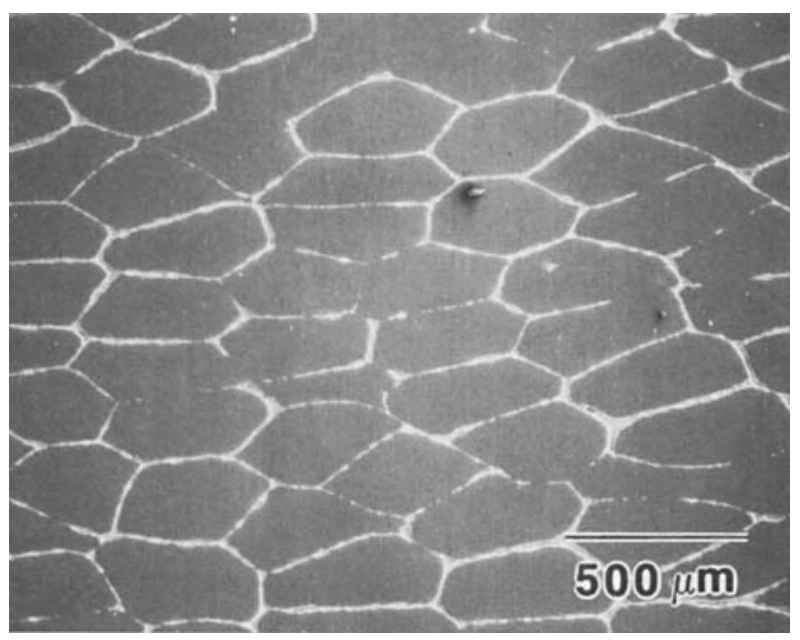

Fig. 6. End-on view of an aligned $\mathrm{Si}_{3} \mathrm{~N}_{4} / \mathrm{BN}$ fibrous monolith prepared with melt-spun fibers. The $\mathrm{BN}\left(+\mathrm{Al}_{2} \mathrm{O}_{3}\right)$ appears bright in the SEM micrograph.

and found no evidence of the fibers in polished sections and fracture surfaces. Similarly, uncoated green fibers of silicon nitride (with yttria + alumina) form monolithic hot-pressed silicon nitride with a microstructure indistinguishable from a body fabricated from ordinary powder.

The cell and cell boundary structure of a fibrous monolith with aligned fibers is illustrated in Fig. 4(A), which is an SEM micrograph of a ground surface of system 1 , the $\mathrm{SiC}$-graphite fibrous monolith. The polycrystalline $\mathrm{SiC}$ cells and graphite cell boundaries are viewed in the hot-pressing direction. The coated fibers had been placed lengthwise from left to right and then pressed. The SiC fibers are greatly flattened in this direction, creating cells about $200 \mu \mathrm{m}$ wide. Note that the width of the graphite cell boundaries are exaggerated by this flattening and the preferential polishing of the soft graphite. A view transverse to the hot-pressing direction, Fig. 4(B), shows that the cells are about $65 \mu \mathrm{m}$ wide in this dimension. The cell lengths vary from a few hundred micrometers to several millimeters. The end-on view of uniaxially aligned $\mathrm{SiC} /$ graphite is presented in Fig. 4(C). The cross section of a pellet that was prepared with randomly oriented finely chopped fibers is shown in Fig. 5. The average width of the cells is again about $60 \mu \mathrm{m}$ but the cell length varies from only 200 to $600 \mu \mathrm{m}$. The graphite cell boundary varies from 1 to $10 \mu \mathrm{m}$ in thickness.

For other fibrous monolith systems, the microstructural dimensions are slightly different. The cell widths depended on how much draw could be obtained during dry spinning, and cell boundary thickness was controlled by coating thickness. The relevant dimensions are mentioned in Section III.

Melt-spun green fibers produce fibrous monoliths with a more uniform network of cells and cell boundaries, a consequence of the constant diameter of melt-spun green fibers. Also, the average cell diameter is larger, a consequence of the larger fiber diameters obtained with our current melt-spinning polymer formulation and spinnerette size. Figure 6 shows an end-on view of a uniaxially aligned silicon nitride/BN fibrous monolith prepared from melt-spun fibers, containing about $10 \mathrm{vol} \%$ boron nitride. The cells are $\approx 165$ by $\approx 360 \mu \mathrm{m}$ in size.

\section{Microstructural Effects on Indentation Behavior}

Vickers indentations ${ }^{\dagger}$ on the surface give rise to complex crack patterns. The size of the indentations are similar to the

${ }^{+}$All indentation work was done with a Vickers diamond on a Zwick machine (Zwick of America, Inc., E. Windsor, CT) with 30-s residence time. cell size, so the fibrous monoliths are quite heterogeneous on the scale of the indentation. Conventional radial/median cracks $^{17}$ do not always form, so indentation methods cannot be used to measure fracture toughness. Nonetheless, crack patterns from indentations serve to illustrate how cracks interact with the cells and cell boundaries. Indentation behavior was studied on randomly oriented chopped fiber monoliths for all systems except for the Ce-TZP/alumina and $\mathrm{Si}_{3} \mathrm{~N}_{4} / \mathrm{BN}$ systems for which aligned-fiber samples were used. All indentation work shown in this study was done on cross-sectional surfaces parallel to the hot-pressing direction.

\section{(1) SiC/Graphite and $\mathrm{Si}_{3} \mathrm{~N}_{4} / B N$}

In the weak interface fibrous monoliths, indentation damage is shown in Fig. 7(A), which is an SEM micrograph of a 50-N Vickers indentation. In this orientation, the cells are relatively narrow, but deep. Indentation causes cells to spall. The stress field around indentations causes subsurface lateral cracks; ${ }^{17}$ the dislodgement of intact cells can be facilitated by lateral cracks along weak cell boundaries. The higher-magnification micrograph in Fig. 7(B) of the same indentation shows that long radial cracks do not emanate from the indentation corner. Instead, some cells are partially cracked and graphite is extruded from the cell boundaries. At lower loads, where the indentation is smaller than the cell size, radial cracks are confined to a single cell, and tend to arrest at the cell boundary. This is illustrated in Fig. 7(C) for an 8-N indent, where radial cracks running up and down do not propagate past the cell boundaries. On surfaces normal to the hot-pressing direction, the cells are wide but shallow; indentation behavior is similar except there is a greater tendency to spall. Silicon nitride/BN fibrous monoliths behave similarly. Silicon nitride cells spall but $\mathrm{BN}$ does not appear to extrude from the cell boundaries.

\section{(2) Alumina /Alumina-Zirconia}

A series of specimens was fabricated in an attempt to develop a microcracked cell boundary containing alumina and unstabilized zirconia. The amount of unstabilized zirconia in the cell boundary was either 20,35 , or 50 vol\%. These compositions were simply chosen on the basis of Claussen's pressure zones $^{2.18}$ in duplex structures. The cell width was $\approx 40 \mu \mathrm{m}$ (normal to the pressing direction) and the cell length varied from 100 to $300 \mu \mathrm{m}$. The cell boundary thickness ranged from $\approx 3$ to $\approx 20 \mu \mathrm{m}$. The sample with a cell boundary containing $50 \mathrm{vol} \%$ $\mathrm{ZrO}_{2}$ cracked on cooling from the hot-pressing temperature. Clearly there was too much residual stress and microcracking to maintain sample integrity. Samples where the cell boundaries contained 20 or 35 vol\% $\mathrm{ZrO}_{2}$ were sound. In system 5, with cell boundaries containing $35 \mathrm{vol} \%$ unstabilized zirconia, X-ray diffraction of a polished surface showed that a significant amount of tetragonal zirconia $(\approx 58 \mathrm{vol} \%$; $\approx 42 \mathrm{vol} \%$ was monoclinic $\left.{ }^{19}\right)$ was present. The tetragonal phase reflects contributions from both the 4 vol\% 3Y-TZP in the cells and the unstabilized tetragonal zirconia retained in the cell boundaries. When indentations (400-N load) were oriented such that indent diagonals were parallel and perpendicular to the pressing direction, cracks normal to the pressing direction preferred to grow along the "weak" cell boundaries. But cracks parallel to the pressing direction were unaffected by cell boundaries. When indentations were oriented such that the radial crack directions were inclined at $45^{\circ}$ to the pressing direction, cells were observed to spall. Cracks from the indentations were not symmetric and showed some tendency to propagate along cell boundaries (see Fig. 8).

\section{(3) Alumina/Aluminum Titanate}

The alumina-aluminum titanate fibrous monolith, system 4 , had cell widths of $39-40 \mu \mathrm{m}$ (normal to the pressing direction) and cell lengths of $150-300 \mu \mathrm{m}$. Cell boundary thickness was 5-10 $\mu \mathrm{m}$. X-ray diffraction confirmed that all the titania from the alumina + titania cell boundaries had fully reacted to form $\mathrm{Al}_{2} \mathrm{TiO}_{5}$. The grain size in the cell. boundary was $2-4 \mu \mathrm{m}$. 


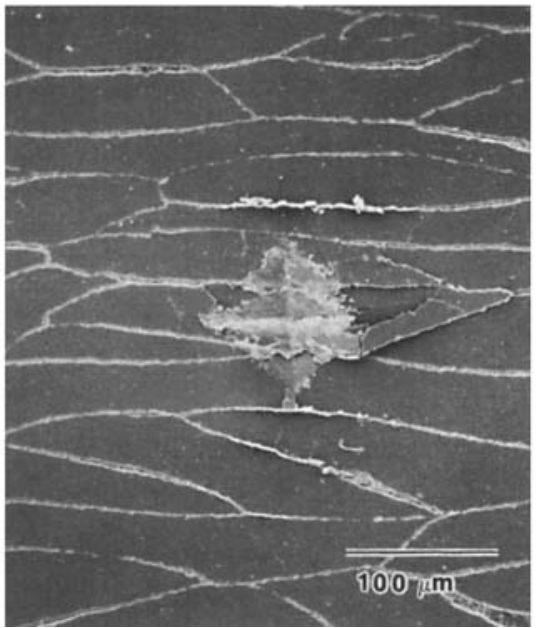

(A)

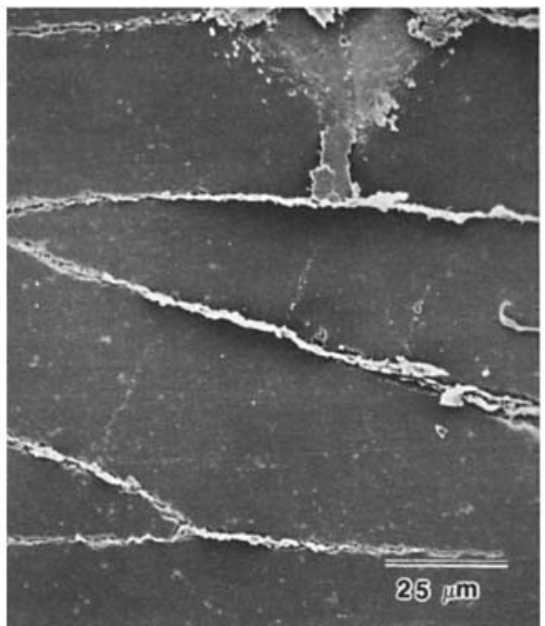

(B)

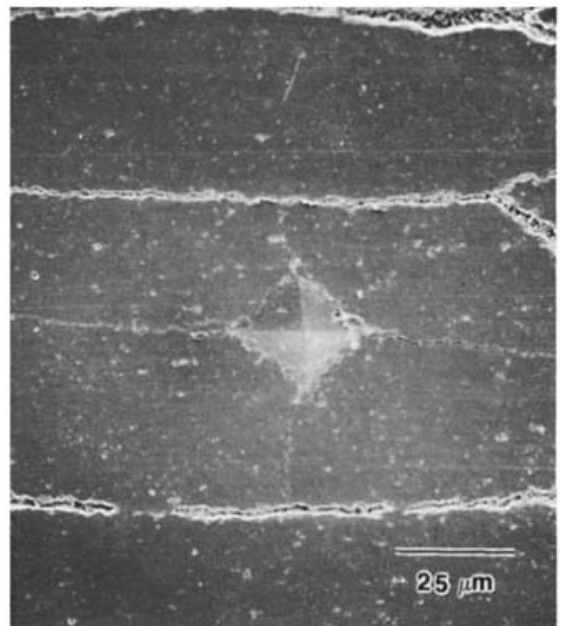

(C)

Fig. 7. SEM micrographs of indentation crack patterns in a SiC/graphite fibrous monolith. Indentation load was $50 \mathrm{~N}$ in (A) and (B) and $8 \mathrm{~N}$ in (C).

Extensive microcracking is known to occur at grain sizes of $3-$ $4 \mu \mathrm{m}$ in single-phase polycrystalline $\mathrm{Al}_{2} \mathrm{TiO}_{5}{ }^{7.8}$

Figure 9 shows a typical radial/median indentation crack running through an aluminum titanate cell boundary. No significant crack deflections or spalling were observed at these aluminum titanate cell boundaries with various indentation loads and orientations. We conclude that this multiphase layout with these particular microstructural dimensions does not generate large stress fields to affect indentation cracking in this system.

\section{(4) Ce-TZP/Alumina + Ce-Zirconia}

The Ce-TZP/alumina-Ce-zirconia system aligned-fiber monolith consisted of Ce-TZP cells $\approx 50-100 \mu \mathrm{m}$ in width (normal to the pressing direction), with alumina-Ce-zirconia cell boundaries $\approx 10-50 \mu \mathrm{m}$ in thickness. From density measurements, we infer that the material consists of 75 vol\%

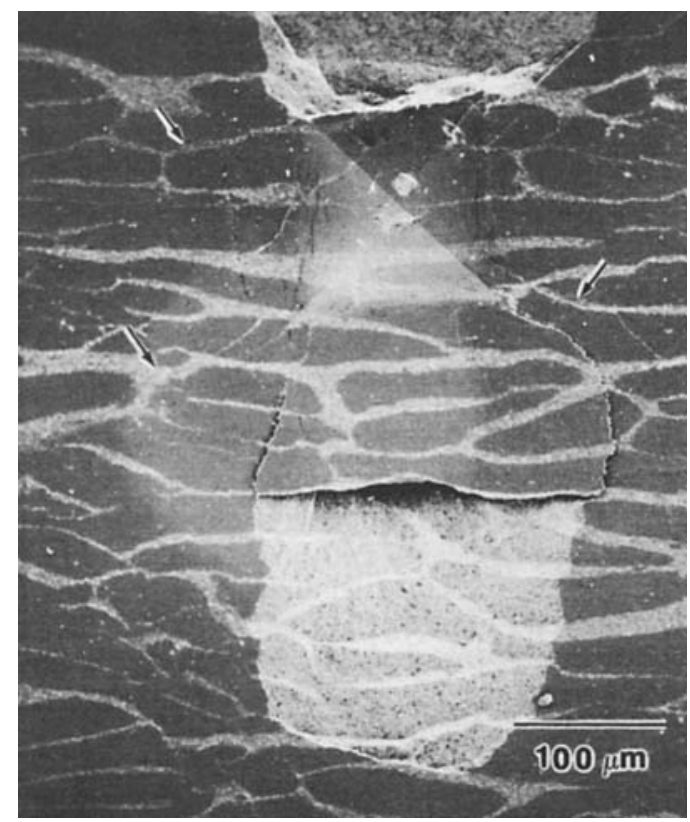

Fig. 8. Indentation fracture in an alumina/(alumina + zirconia) fibrous monolith. Viewed normal to the hot-pressing direction. Indentation (400-N load) diagonals oriented at $45^{\circ}$ to the hot-pressing direction. Arrows indicate cracks from the indentation. The cell boundaries appear bright in the SEM micrograph.
Ce-zirconia +25 vol\% alumina, but fabricated as a fibrous monolith with pure Ce-TZP cells, and cell boundaries with a composition of 50 vol\% Ce-zirconia +50 vol\% alumina. Thus the cells occupy $50 \mathrm{vol} \%$ of the material, and the cell boundaries occupy $50 \%$.

An optical micrograph (Nomarski interference) of a $200-\mathrm{N}$ indentation in this system is shown in Fig. 10. The bright regions in the Ce-TZP cells near (especially above) the indentation show the uplift of transformed regions, indicating that transformation zone shapes can be modified by adopting this microstructural design. Compared to the colloidally fabricated $\mathrm{Ce}-\mathrm{TZP} /$ alumina laminates, ${ }^{10}$ there is less uniformity in microstructural dimensions in the fibrous monolith. The shape of the indentation and the asymmetric nature of the transformation zone uplift reflect the nonuniformity in cell/cell boundary dimensions and cell depth beneath the surface. However, there

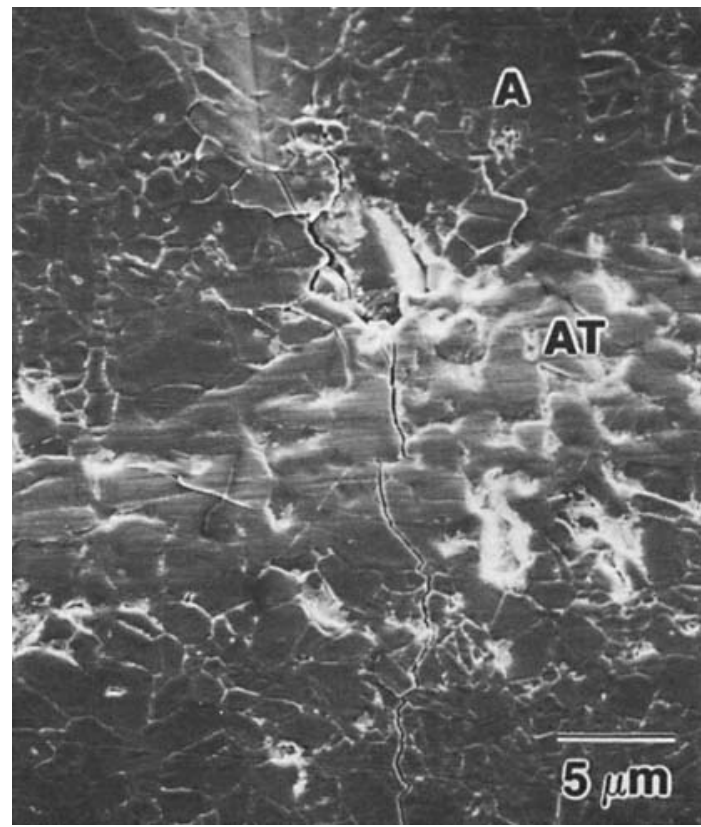

Fig. 9. SEM micrograph showing indentation crack (100-N load) intersecting an aluminum titanate cell boundary in an alumina (A)/aluminum titanate (AT) sample. 


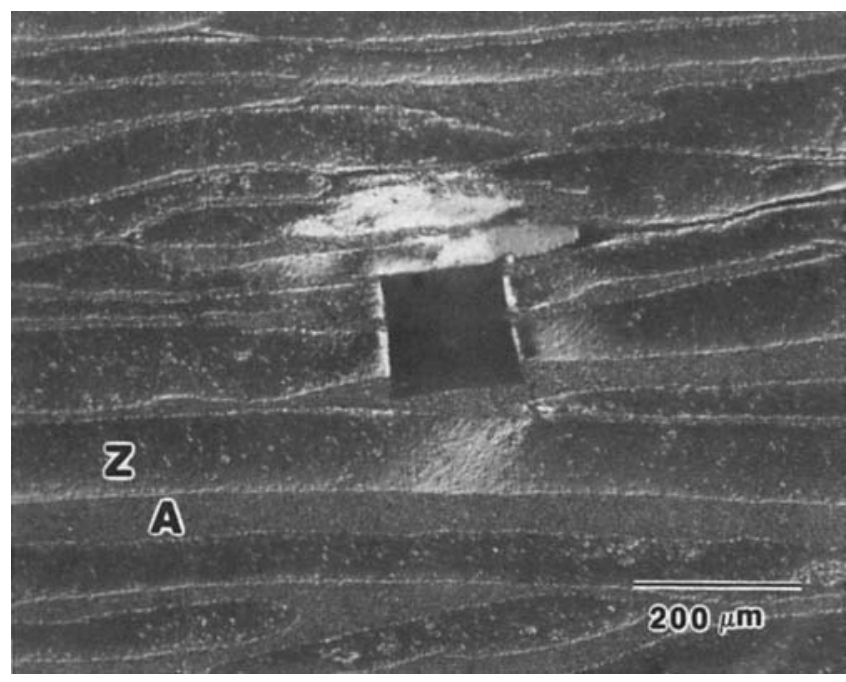

Fig. 10. Optical micrograph (Nomarski interference) of a $200-\mathrm{N}$ indentation in an aligned-fiber $\mathrm{Ce}-\mathrm{TZP} /$ alumina-Ce-zirconia sample. Viewed normal to the hot-pressing direction. $Z=C e-T Z P, A=$ alumina + Ce-zirconia.

is clearly potential for developing tough Ce-TZP/alumina fibrous monoliths.

\section{(5) Alumina/Nickel}

Some preliminary experiments show that it is feasible to produce a fibrous monolith with ductile phase cell boundaries. Figure 11(A) shows the polished surface, viewed in the hotpressing direction, of an alumina/Ni fibrous monolith, system 6 . The cell widths were again about $200 \mu \mathrm{m}$ viewed in the pressing direction and $40-60 \mu \mathrm{m}$ normal to the pressing direction. This specimen was a random compacted felt. It was difficult to polish this specimen, and the amount of $\mathrm{Ni}$ is greatly exaggerated by polishing artifacts. Density measurements indicate that the actual volume fraction of nickel is only about $3 \%$. This is consistent with the appearance of the fracture surface of a broken pellet (Fig. 11 (B)). In the central part of Fig. 11(B), where the alumina cells are oriented horizontally, the nickel can be seen to consist of thin ribbons between the polycrystalline alu-mina cells. The ductility of the nickel and its weak adhesion to the alumina are indicated by the peeled-off nickel ribbons. The data of Tuan and Brook ${ }^{20}$ for particulate alumina-Ni show a significant toughening increment with $\mathrm{Ni}$ additions. Improved toughness and noncatastrophic fracture behavior in alumina-Ni fibrous monoliths will be reported in a subsequent paper. Indentation behavior in this system was not studied.

\section{Flexural Strength of SiC/Graphite}

Strengths were measured for the $\mathrm{SiC} / g r a p h i t e$ system with aligned fibers using $\approx 3 \mathrm{~mm} \times 4 \mathrm{~mm} \times 47 \mathrm{~mm}$ specimens tested in four-point bending with a 20 -mm inner span and 40-mm outer span at a crosshead speed of $0.05 \mathrm{~mm} / \mathrm{min}$. Specimens had been machined and chamfered with a 1000-grit resinbonded diamond wheel, with the machining direction along the axis of the bar.

The SiC/graphite fibrous monoliths showed unusual and potentially useful fracture behavior. Failure in flexure occurred in a noncatastrophic manner. A typical load-deflection curve for this system is shown in Fig. 12(A). The fibrous monolith behaves like a typical monolithic ceramic until a stress of $\approx 220$ $\mathrm{MPa}$ is reached at the tensile surface, beyond which the load drops in a gradual manner. Load drops were accompanied by shear delamination along the graphitic cell boundaries which were parallel to the tensile surface. The bar specimen was removed when the load was less than $30 \mathrm{~N}$, and pulled apart by hand. The fracture surface is shown in Fig. 12(B). The terraced appearance reflects the deflection of the crack path at each successive cell boundary and delamination along the cell boundaries. The apparent work-of-fracture evaluated from the load deflection curve was $\approx 1450 \mathrm{~J} / \mathrm{m}^{2}$. The work-of-fracture measured for fibrous materials will depend on the loading configuration $^{21}$ and specimen dimensions, but the calculated value demonstrates the high toughness possible in weak interface fibrous monolithic ceramic systems. The fracture behavior of $\mathrm{SiC} / \mathrm{graphite}$ fibrous monoliths is presented in detail elsewhere. ${ }^{11}$
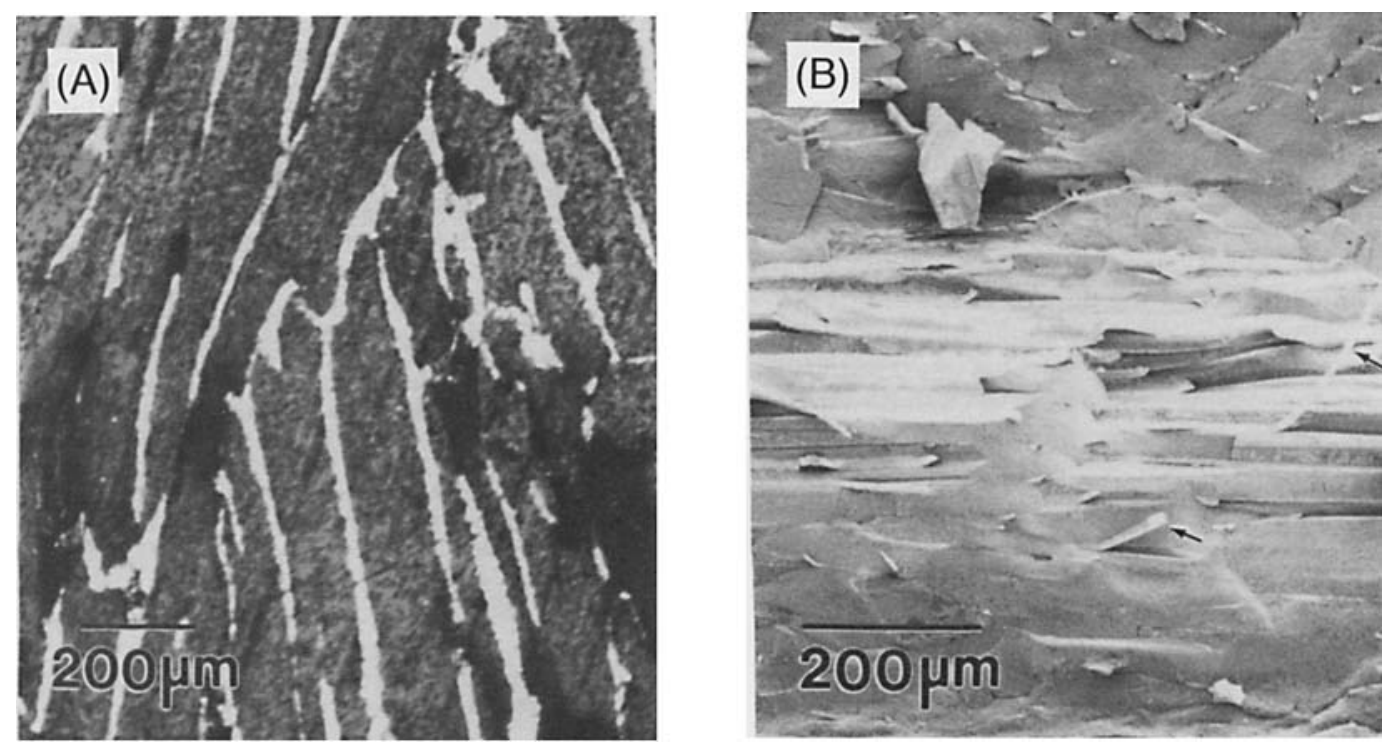

Fig. 11. (A) Optical micrograph of a polished surface of an alumina/Ni fibrous monolith viewed in the hot-pressing direction. (B) SEM micrograph of a fracture surface of an alumina/Ni fibrous monolith. Peeled-off nickel ribbons indicated by arrows. 

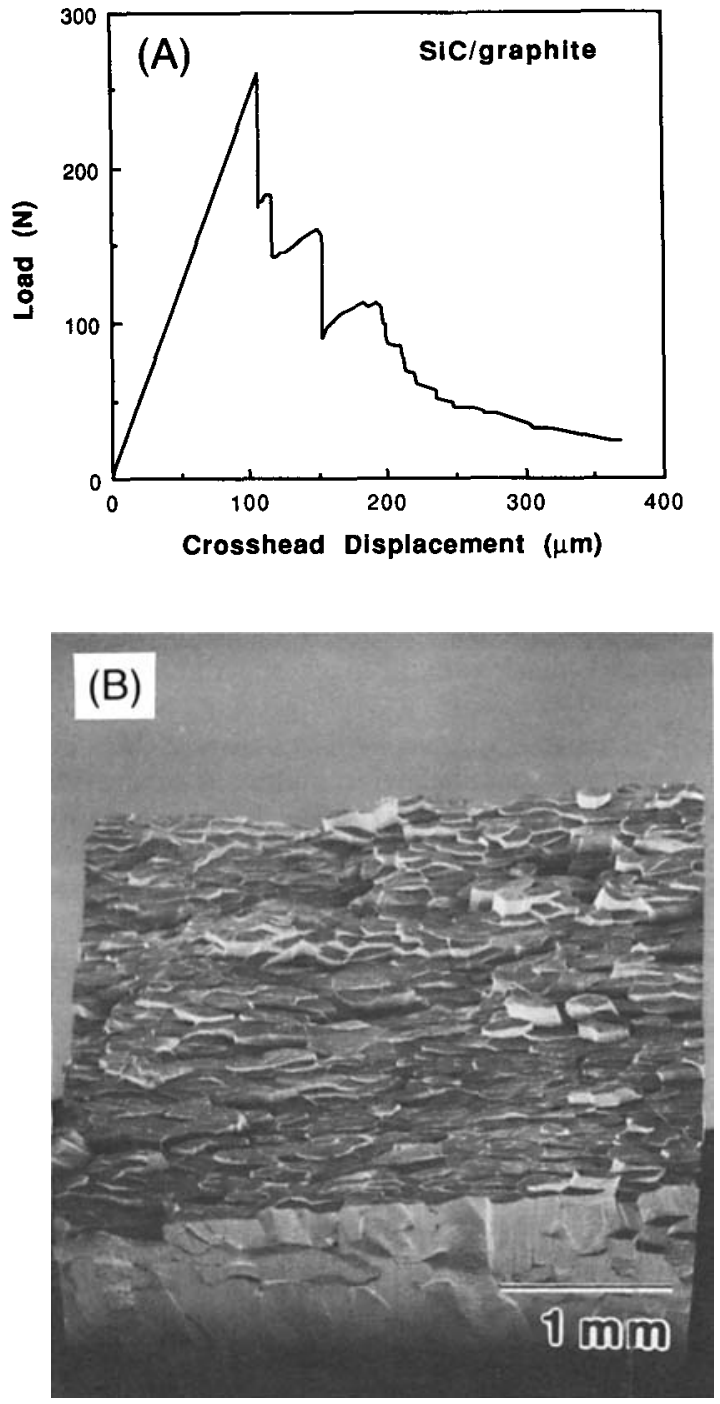

Fig. 12. (A) Load-deflection curve for a SiC/graphite fibrous monolith bend specimen prepared with aligned fibers. (B) Fracture surface of the sample. The compressive side of the bar specimen is visible in the lower part of the SEM micrograph.

\section{Conclusion}

We have demonstrated the fabrication of dense fibrous monolithic ceramics from coated ceramic green fiber to create microstructures with high aspect ratio polycrystalline cells separated by thin cell boundaries to improve the mechanical properties. A variety of ceramic systems have been fabricated in fibrous monolith form, demonstrating the versatility of this processing route/microstructural design. Indentation fracture in these materials is complex as would be expected in a dual-phase microstructure, with dimensions comparable to the indentation.

Our results indicate that weak-interface fibrous monoliths such as $\mathrm{SiC} /$ graphite or $\mathrm{Si}_{3} \mathrm{~N}_{4} / \mathrm{BN}$ have potential as damage-tolerant materials. In these materials, controlled damage around indentations prevents the formation of long radial cracks. Also, preferential crack propagation along the graphitic cell bound- aries, which act as weak interfaces, leads to noncatastrophic failure by shear delamination in $\mathrm{SiC} / g r a p h i t e$, a behavior similar to ceramic-matrix composites reinforced by high-strength fibers.

Several oxide-based fibrous monoliths are also promising. Indentation of alumina/alumina-zirconia fibrous monoliths results in complex crack patterns and spalling in some orientations. Potential also exists for developing useful Ce-TZP/alumina fibrous monoliths. Transformed regions near indentations are altered by the alumina-containing cell boundaries. Fibrous monoliths were also fabricated in the alumina/aluminum titanate and alumina/nickel systems. Further work is required to establish whether suitably engineered aluminum titanate cell boundaries can be useful. With higher amounts of nickel, the fibrous monolith approach offers a convenient method of fabricating textured ceramics containing ductile, metallic interphases.

Acknowledgments: We thank Timothy Fretter and Lynne Svedberg for their valuable assistance in the laboratory.

\section{References}

'M. P. Harmer, H. M. Chan, and Gary A. Miller, "Unique Opportunities for Microstructural Engineering with Duplex and Laminar Ceramic Composites," J. Am. Ceram. Soc., 75 [7] 1715-28 (1992).

${ }^{2}$ W. J. Clegg, K. Kendall, N. McN. Alford, T. W. Button, and J. D. Birchail, "A Simple Way to Make Tough Ceramics," Nature (London), 347, 455-57 (1990).

${ }^{3}$ N. Claussen, "Microstructural Design of Zirconia-Toughened Ceramics (ZTC)"; pp. 325-51 in Advances in Ceramics, Vol. 12, Science and Technology of Zirconia 1 . Edited by N. Claussen, M. Rühle, and A. H. Heuer. American Ceramic Society, Columbus, OH, 1984.

${ }^{4}$ S. J. Bennison, N. P. Padture, J. L. Runyan, and B. R. Lawn, "Flaw-Insensitive Ceramics," Philos. Mag. Lett., 64 [4] 191-95 (1991).

${ }^{5}$ N. P. Padture, S. J. Bennison, and H. M. Chan, "Flaw-Tolerance and Crack Resistance Properties of High Toughness Alumina-Aluminum Titanate Composites with Tailored Microstructures," J. Am. Ceram. Soc., in press.

${ }^{6}$ W. S. Coblenz, "Fibrous Monolithic Ceramic and Method for Production," U.S. Pat. No. 4772524 , September 20, 1988.

${ }^{7}$ F. J. Parker and R. W. Rice, "Correlation between Grain Size and Thermal Expansion for Aluminum Titanate Materials," J. Am. Ceram. Soc., 72 [12] 2364-66 (1989),

${ }^{8}$ J. J. Cleveland and R. C. Bradt, "Grain Size/Microcracking Relations for Pseudobrookite Oxides," J. Am. Ceram. Soc., 61 [11-12] 478-81 (1978).

${ }^{9}$ J. L. Runyan and S. J. Bennison, "Fabrication of Flaw-Tolerant AluminaAluminium Titanate Composites," J. Eur. Ceram. Soc., 7, 93-99 (1991).

${ }^{10}$ D. B. Marshall, J. J. Ratto, and F. F. Lange, "Enhanced Fracture Toughness in Layered Microcomposites of $\mathrm{Ce}-\mathrm{ZrO}_{2}$ and $\mathrm{Al}_{2} \mathrm{O}_{3}$," J. Am. Ceram. Soc., 74 [12] 2979-87 (1991).

"S. Baskaran and J. W. Halloran, "Fibrous Monolithic Ceramics: II, Flexural Strength and Fracture Behavior of the Silicon Carbide/Graphite System," J. Am. Ceram. Soc., 76 [9] 2217-24 (1993).

${ }^{12}$ S. D. Nunn, D. Popovic, S. Baskaran, J. W. Halloran, G. Subramanian, and S. G. Bike, "Suspension Dry Spinning and Rheological Behavior of Ceramic Green Fibers," J.Am. Ceram. Soc, in review.

${ }^{13}$ L. D. Hart and A. Pearson, "Production of Continuous Ceramic Fibers: Polyethylene Oxide Polymers," U.S. Pat. No. 4071 594, January 31, 1978.

${ }^{14}$ J. W. Halloran, J. D. Hodge, D. Chandler, L. J. Klemptner, M. J. Neal, M. V. Parish, H. D. Park, V. M. Pathare, G. Bakis, and D. Eagles, "Fabrication and Properties of High Temperature Superconductor Wire by the Green Fiber Method," J. Am. Ceram. Soc., 75 [4] 903-907 (1992).

${ }^{15}$ F. J. Frechette, W. D. G. Boecker, C. H. McMurtry, and M. R. Kasprzyk, "Non-Oxide Sintered Ceramic Fibers," U.S. Pat. No. 4908 340, March 13, 1990.

${ }^{16} \mathrm{R}$. B. Cass, "Fabrication of Continuous Ceramic Fiber by the Viscous Suspension Spinning Process," Am. Ceram. Soc. Bull., 70 [3] 424, 426, 428-29 (1991).

${ }^{17}$ B. R. Lawn and M. V. Swain, "Microfracture beneath Point Indentations in Brittle Solids," J.Mater. Sci., 10, 113-22 (1975).

${ }^{18}$ H. E. Lutz and N. Claussen, "Duplex Ceramics: I, Stress Calculations, Fabrication and Microstructure," J. Eur. Ceram. Soc., 7, 209-18 (1991).

${ }^{19}$ R. C. Garvie and P. S. Nicholson, "Phase Analysis in Zirconia Systems," J. Am. Ceram. Soc., 55 [6] 303-305 (1972).

${ }^{20}$ W. H. Tuan and R. J. Brook, "The Toughening of Alumina with Nickel Inclusions," J. Eur. Ceram. Soc., 6, 31-37 (1990).

${ }^{21}$ A. G. Evans and D. B. Marshall, "Failure Mechanisms in Ceramic Fiber/ Ceramic Matrix Composites,"J. Am. Ceram. Soc., 68 [5] 225-31 (1985). 